\title{
Biogeography of Triatominae (Hemiptera: Reduviidae) in Ecuador: Implications for the Design of Control Strategies
}

\author{
Fernando Abad-Franch/*, Aura Paucar C* $/++$, Carlos Carpio C*, \\ César A Cuba Cuba**, H Marcelo Aguilar V*/***, Michael A Miles/ ${ }^{+}$
}

Pathogen Molecular Biology and Biochemistry Unit, Department of Infectious and Tropical Diseases, London School of Hygiene and Tropical Medicine, Keppel St., London WC1E 7HT, UK *Unidad de Medicina Tropical,

Instituto 'Juan César García', Quito, Ecuador **Unidade de Parasitologia Médica-Patologia, Faculdade de Medicina, Universidade de Brasília, DF, Brasil ***Instituto Nacional de Higiene y Medicina Tropical 'Leopoldo Izquieta Pérez', Quito, Ecuador

Chagas disease control strategies strongly depend on the triatomine vector species involved in Trypanosoma cruzi transmission within each area. Here we report the results of the identification of specimens belonging to various species of Triatominae captured in Ecuador (15 species from 17 provinces) and deposited in the entomological collections of the Catholic University of Ecuador (Quito), Instituto Oswaldo Cruz (Brazil), the Natural History Museum London (UK), the London School of Hygiene and Tropical Medicine (UK), the National Institute of Hygiene (Quito), and the Vozandes Hospital (Quito). A critical review of published information and new field records are presented. We analysed these data in relation to the life zones where triatomines occur (11 life zones, excluding those over 2,200 $\mathrm{m}$ altitude), and provide biogeographical maps for each species. These records are discussed in terms of epidemiological significance and design of control strategies. Findings relevant to the control of the main vector species are emphasised. Different lines of evidence suggest that Triatoma dimidiata is not native to Ecuador-Peru, and that synanthropic populations of Rhodnius ecuadoriensis in southern Ecuador-northern Peru might be isolated from their sylvatic conspecifics. Local eradication of $\mathrm{T}$. dimidiata and these $\mathrm{R}$. ecuadoriensis populations might therefore be attainable. However, the presence of a wide variety of native species indicates the necessity for a strong longitudinal surveillance system.

Key words: Triatominae - biogeography - Chagas disease - control - Triatoma dimidiata -

Rhodnius ecuadoriensis - Ecuador

Around 3 million people live under risk conditions for Trypanosoma cruzi transmission in Ecuador; prevalence estimates indicate that $\sim 150,000$ people are already infected (Aguilar et al. 1999). Sixteen triatomine species have been reported from the country (excluding doubtful records of Triatoma infestans and Rhodnius prolixus) (Aguilar et al. 1999). At least 13 of these species (see Tables

Supported by the UNDP/World Bank/WHO TDR (Grant 970195), the ECLAT Network, the Tropical Medicine Unit at the University General Hospital of Valencia (Spain), the Cañada-Blanch Foundation (Spain), and Capes (Ministério de Educação e Cultura, Brasil).

+Corresponding author. Fax: +44-207-636.8739. E-mail: michael.miles@1shtm.ac.uk

${ }^{++}$Current address: Systematics Research Collections, W436 Nebraska Hall, University of Nebraska State Museum Lincoln, NE 68588-0514 USA

Received 31 July 2000

Accepted 21 November 2000
I-III) are actual or potential vectors of Chagas disease (Lent \& Wygodzinsky 1979, WHO 1991, Abad-Franch 2000). This complex situation is currently being investigated in the context of the $\mathrm{Na}$ tional Programme for Chagas Disease Control in Ecuador. Our aim is to contribute to these efforts by analysing and completing the relevant information about Chagas disease triatomine vectors in Ecuador.

From 1998 to 2000, and as part of our research on the epidemiological significance of Rhodnius species in Ecuador and Peru, we undertook a revision of the Triatominae kept at various important entomological collections. During that revision, new data on distribution of some species in Ecuador became apparent. We added entomological records from our own fieldwork and from research being carried out by Ecuadorian colleagues. Here we report those new records, together with previously published data, and analyse them in relation to the main ecological and epidemiological traits of the different species. Finally, recommendations on vector control strategies are put forward. 


\section{MATERIALS AND METHODS}

For this study, we reviewed available published reports, and the specimens belonging to the subfamily Triatominae deposited at the Invertebrate Museum of the Catholic University of Ecuador, Quito, the Herman Lent and Rodolfo Carcavallo Collections (Laboratório Nacional e Internacional de Referência em Taxonomia de Triatomíneos, Departamento de Entomologia, Instituto Oswaldo Cruz, Rio de Janeiro, Brazil), the Natural History Museum, London (UK), the London School of Hygiene and Tropical Medicine (UK), the Vozandes Hospital (Quito, Ecuador), and the National Institute of Hygiene and Tropical Medicine (Quito, Ecuador). Fieldwork and unpublished records were also included in our analysis.

Notes on epidemiological significance of each species were prepared on the basis of published information, unpublished reports, and field observations. For geographical information, we used the guide by Miranda (1995), the "Índice Toponímico" of the Instituto Geográfico Militar (IGM 1978-82, 1982-96), and cartographic material provided by the IGM. Life zones were established following the ecological maps proposed by Cañadas (1983) and Cañadas and Estrada (1978, cf. Dodson \& Gentry 1991), based on the life zones described by Holdridge (1967). We included life zones under 2,200 $\mathrm{m}$ altitude in the analysis. In the distribution maps (Figure), marks indicate places of capture. Life zones where each species occur are light grey, and we added the outline and number of the life zones representing the potential distribution of each species (areas from where no records exist, but where ecological features are identical to other zones where captures have been made).

\section{RESULTS*}

Results on geographical and ecological distribution of species are shown in the Figure and in Tables I-III; 17 out of 21 provinces have produced records of triatomines (excluding doubtful reports from two more provinces). The studied species occupy 11 life zones in Ecuador. Life zones in the Andes range (2,200-6,310 m altitude) were not included in the analysis; apparently, only $T$. carrioni occurs there. Annual rains in areas where triatomines occur range between $62.5-125 \mathrm{~mm} /$ year in the tropical desert and 2,000-4,000 mm/year in the wet and

\footnotetext{
*New field records were obtained after the preparation of the manuscript (province of Pichincha, life zone 9): Triatoma dimidiata (domestic colony), Rhodnius ecuadoriensis (adults in house), and Panstrongylus rufotuberculatus (adults in houses).
}

moist forests (Table IV). Average temperatures ranged from $12-18^{\circ} \mathrm{C}$ in the low montane forest areas to $24-26^{\circ} \mathrm{C}$ in the coastal dry tropical forests (Table IV). Altitude range was 0-2,650 m (Tables I, IV). The maximum number of species recorded in a single life zone corresponds to the Amazon rainforest (seven species, excluding unconfirmed records of T. dimidiata and R. ecuadoriensis). These two latter species, deemed the main Chagas disease vectors in the country, have the widest distribution range; $T$. dimidiata has been reported from six different life zones in the country and R. ecuadoriensis from five (see Tables I, II, IV). The distributions of these and all the other species in relation to life zones are also summarised in Table IV.

No records from the Galápagos Islands were found.

\section{DISCUSSION}

Complementary sampling and further analysis are indispensable to achieve an accurate idea of how triatomines are distributed in Ecuador, the way they are related to different ecological zones, their synanthropic behaviour, and their inter- and intraspecific relations. Records from some provinces are limited or do not exist. The ecological complexity of Ecuador is illustrated in the diversity of life zones (from desertic areas to pluvial forests). The high number of triatomine species also reflects such diversity.

T. dimidiata occurs only in low, dry areas of the coast, including the tropical desert in the Santa Elena peninsula (Guayas), and seems to be always in a domestic habitat. Only one report of adult specimens found in an allegedly sylvatic environment (under the bark of a dead tree) (cf. Zeledón 1981) was found. However, the actual presence of sylvatic colonies of this species in Ecuador has never been documented; specimens found in peridomestic terrestrial bromeliads and periurban rubbish dumps in Manabí (Vector Control Service, unpublished observations) cannot be considered as truly sylvatic. This fact, together with the apparent discontinuity in the distribution of the species from Mexico to Ecuador (absent from southern Colombia, except in some localities of the upper Magdalena valley) (Zeledón 1981, D’Alessandro \& Barreto 1985, Carcavallo et al. 1999), makes us contemplate the hypothesis that it was introduced into coastal areas of Ecuador and Peru. Sea trade is known to have linked Mesoamerican and Ecuadorian-Peruvian cultures from $\sim 1500 \mathrm{BC}$ (Meggers \& Evans 1963). As pointed out by Schofield et al. (1999), genetic and phenetic simplification generally impedes the re-adaptation of strictly domestic triatomines to new, unstable sylvatic habitats. If the introduction of such $T$. dimidiata populations 

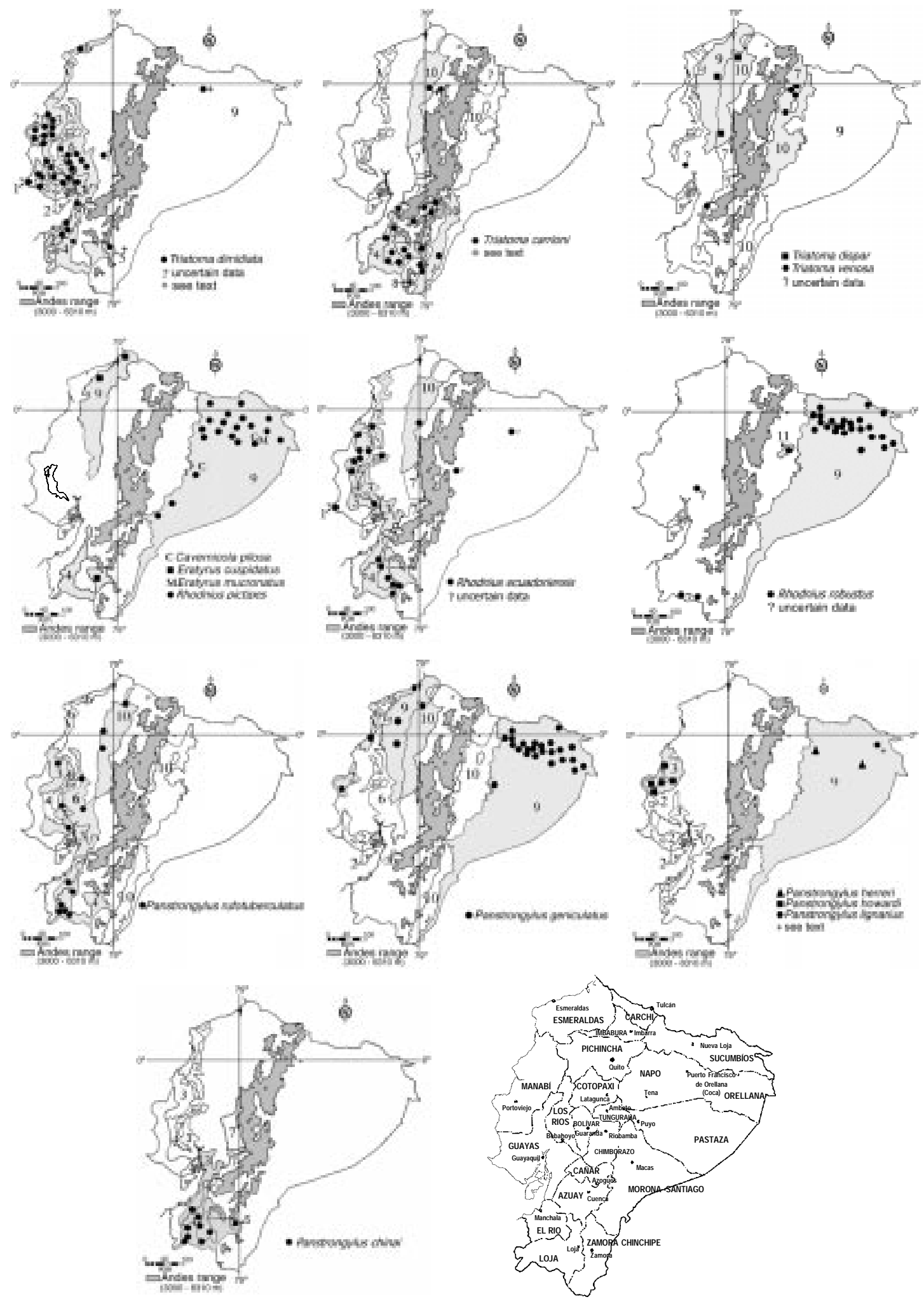

Biogeography of Ecuadorian Triatominae. Life zones - 1: tropical desert; 2: thick tropical bush; 3: very dry tropical forest; 4: dry premontane forest; 5: dry low montane forest; 6: dry tropical forest; 7: humid premontane forest; 8: humid low montane forest; 9: moist tropical forest; 10: wet premontane forest; 11: wet low montane forest (Ecuador Provinces); actual distribution: light grey areas; potential distribution: outlined white areas with number of life zone. 
to Ecuador-Peru is confirmed, meaning that no sylvatic populations of $T$. dimidiata occur in Ecuador, then the species might be a suitable target for local eradication (pyrethroid insecticide spraying of all dwellings in positive localities is recommended in such a situation) (Acevedo et al. 2000, Schofield 2000). Preliminary results of nuclear and mitochondrial gene sequencing (Bargues et al. 2000, Marcilla et al. 2001, Solís-Mena et al. unpublished data) and morphometry (Solís-Mena et al. 2000) are lending support to this hypothesis. Recently, three $T$. dimidiata adults were allegedly collected in a dwelling in the Ecuadorian Amazon; however this finding needs further confirmation.

$R$. ecuadoriensis colonises human environments in central and southern Ecuadorian provinces west of the Andes, and in northern Peru. Sylvatic populations seem primarily associated with the endemic Phytelephas aequatorialis palm trees in the central coastal region (Romaña et al. 1994, Avilés et al. 1995a, Abad-Franch et al. 2000). We recently found $27 \%$ of $64 P$. aequatorialis palms to harbour $R$. ecuadoriensis breeding colonies in three provinces of the Pacific slope of the Andes (Abad-Franch 2000); both invasion and colonisation of human habitats by wild insects have

TABLE I

Distribution and epidemiological significance of the Triatoma Laporte, Eratyrus Stal, and Cavernicola Barber species in Ecuador

\begin{tabular}{lll}
\hline Species & $\begin{array}{l}\text { Distribution } \\
\text { (provinces) }^{a}\end{array}$ & $\begin{array}{l}\text { Epidemiological } \\
\text { significance }\end{array}$ \\
\hline $\begin{array}{l}\text { Triatoma dimidiata } \\
\text { (Latreille) }\end{array}$ & $\begin{array}{l}\text { Manabí, Guayas, } \\
\text { El Oro, Los Ríos, } \\
\text { Loja, Esmeraldas } \\
\text { Uncertain finding } \\
\text { in the Amazon } \\
\text { region (Napo) }\end{array}$ & $\begin{array}{l}\text { The main Trypanosoma } \\
\text { cruector in the country; } \\
\text { responsible for the urban } \\
\text { endemicity in the city of } \\
\text { Guayaquil and for the } \\
\text { maintenance of the } \\
\text { transmission in other areas }\end{array}$
\end{tabular}

Triatoma carrioni

Larrousse

Loja, Azuay, Cañar, El Oro, Pichincha, Cotopaxi, Zamora Chinchipe

$\begin{array}{ll}\begin{array}{ll}\text { Triatoma venosa } \\ \text { (Stål) }\end{array} & \begin{array}{l}\text { Azuay, Napo/ } \\ \text { Orellana } b\end{array} \\ & \\ \begin{array}{l}\text { Triatoma dispar } \\ \text { Lent }\end{array} & \begin{array}{l}\text { Imbabura, } \\ \text { Cotopaxi }\end{array} \\ \begin{array}{l}\text { Eratyrus mucronatus } \\ \text { Stål }\end{array} & \text { Napo/Orellana }\end{array}$

Sylvatic in Ecuador domestic colonies reported from Colombia; high altitudes

Strictly sylvatic

Sylvatic in Ecuador; reports of domestic colonies in Bolivia

$\begin{array}{lll}\text { Eratyrus cuspidatus } & \text { Loja, Esmeraldas } & \text { Sylvatic } \\ \text { Stål } & \\ \text { Cavernicola pilosa } & \text { Napo/Orellana }{ }^{b}, & \text { Sylvatic } \\ \text { Barber } & \text { Pastaza } & \end{array}$

Observations

Dry life zones in central and southern coastal region; the apparent discontinuity in its distribution from Colombia to Peru merits further investigation; sylvatic ecotopes in Ecuador unknown; genetic and morphometric similarities with Mesoamerican specimens; its presence in the Amazon needs confirmation

Temperate valleys and highlands of the Andean southern cordillera; records from the Amazon slope of Andes and northern Ecuador merit further confirmation; a V instar nymph apparently belonging to this species was captured in a bromeliad epiphyte in La Otonga, Cotopaxi (primary cloud forest, $>2,000 \mathrm{~m}$ altitude)

Up to 2,200 m altitude

Andean region; one record from Guayas probably erroneous

Amazon region (primary forest; two specimens captured by light trapping); one record from Esmeraldas is probably due to misidentification

Coastal region and low areas of the western Andes

Amazon region (one specimen captured by light trapping)

$a$ : Reports on distribution: T. dimidiata: Lent \& Wygodzinsky 1979, Lazo 1985, Defranc 1982, this report; $T$. carrioni: Leon 1949, Espinoza 1955, Lent \& Wygodzinsky 1979, Defranc 1982, Reyes 1982, this report; T. venosa: Defranc 1982, Lent \& Wygodzinsky 1979, this report; T. dispar: Lent \& Wygodzinsky 1979, this report; E. mucronatus: Defranc 1982, Lent \& Wygodzinsky 1979, this report; E. cuspidatus: Defranc 1982; C. pilosa: Lent \& Wygodzinsky 1979, this report; $b$ : Napo and Orellana were separated into two provinces in 1998. 
been documented in coastal Ecuador (Defranc 1987, Abad-Franch 2000). Treatment of infested dwellings and monitoring of re-infestations should be the recommended control strategy there. We also studied the presence of $R$. ecuadoriensis in temperate valleys of the provinces of Loja and El Oro (near the Peruvian border). Palm trees are completely absent in the studied areas, probably due to massive deforestation that occurred in the last 3040 years (Dodson \& Gentry 1991). Nine percent of 118 dwellings surveyed in two communities were infested (crowding indices from 42 to 78), with the majority of colonies breeding in peridomestic chicken coops, but also inside houses - mainly in beds and mud walls (Abad-Franch 2000). It is of greater importance for the control of this species in southern Ecuador and northern Peru to determine whether sylvatic populations still occur there (making re-infestation likely), or if domestic insects have become isolated from their wild conspecifics as a consequence of deforestation (local eradication could be attainable in this case). We have also detected the presence of strictly wild
R. ecuadoriensis forms in northern Ecuador; their specific status needs however to be confirmed (Abad-Franch 2000, Abad-Franch et al. 2000). Finally, we found two specimens labelled as collected on the eastern slope of the Andes (marked as uncertain data on the map, as we suspect erroneous places of capture indicated on labels).

T. carrioni, an endemic species that has adapted to human habitats in the Andean valleys of southern Ecuador and northern Peru, occupies a wide range of life zones (dry and humid, 1,000-2,650 m altitude) and has been reported to feed on humans and horses (Lent \& Wygodzinsky 1979). An adult specimen was recently captured by light trapping in the northern province of Pichincha. A nymph apparently belonging to this species was captured in an epiphytic bromeliad in the canopy of primary cloud forest in a neighbouring area (Figure, Table I). In the southern Andean provinces of Loja and Azuay, the species has been found in human-related habitats both in rural and urban areas (León 1949, Espinoza 1955, Defranc 1982). Some capture places (marked with + in the Figure) are lo-

\section{TABLE II}

Distribution and epidemiological significance of the Rhodnius Stål species in Ecuador

\begin{tabular}{lll}
\hline Species & $\begin{array}{l}\text { Distribution } \\
\text { (provinces) }\end{array}$ & $\begin{array}{l}\text { Epidemiological } \\
\text { significance }\end{array}$ \\
\hline $\begin{array}{l}\text { Rhodnius } \\
\text { ecuadoriensis } \\
\text { Lent \& León }\end{array}$ & $\begin{array}{l}\text { Manabí, Guayas, } \\
\text { Losios, El Oro, } \\
\text { Loja, Pichincha }\end{array}$ & $\begin{array}{l}\text { Considered as the second main } \\
\text { Trypanosoma cruzi vector in the } \\
\text { country; able to invade-colonise } \\
\text { human environments, and found to } \\
\text { breed even within dwellings in } \\
\text { good condition; related to domestic } \\
\text { birds (chicken, pigeons) and, in } \\
\text { wild environments in northern and } \\
\text { central Ecuador, to palm trees } \\
\text { (Phytelephas aequatorialis); sylvatic } \\
\end{array}$ \\
& & $\begin{array}{l}\text { populations not reported from } \\
\text { southern Ecuador nor northern Peru }\end{array}$ \\
&
\end{tabular}

$\begin{array}{ll}\begin{array}{l}\text { Rhodnius } \\ \text { pictipes }\end{array} & \text { Sucumbíos, } \\ \text { Stål } & \text { Napo/Orellana }{ }^{b}, \\ & \text { Morona-Santiago }\end{array}$

$\begin{array}{ll}\text { Rhodnius } & \text { Sucumbíos, } \\ \text { robustus } & \text { Napo/Orellana }\end{array}$
Probably involved in the transmission of T. cruzi in some areas; adults flying into houses, even in urban areas (unpublished observation)

Probably involved in the transmission of $T$. cruzi in some areas; adults flying into houses
Observations

Central and southern coastal region; sylvatic populations reported from Manabí, Los Ríos, and Pichincha (the taxonomic status of these latter is under investigation)

Amazon region; we studied the presence of $R$. stali, a species very closely related to $R$. pictipes, in the Ecuadorian Amazon, with negative results (unpublished data); present in palm trees of at least five genera in Sucumbíos (unpubl.)

Amazon region; palm trees of at least five genera in Sucumbíos (unpubl.); labelling errors probably involved in the finding of specimens allegedly collected in the Coastal region

$a$ : Reports on distribution: R. ecuadoriensis: Lazo 1985, Defranc 1982, Carcavallo \& Martínez 1985, Romaña et al. 1994, Abad-Franch et al. 2000, this report; R. pictipes: Espinoza 1955, Amunárriz 1991, Amunárriz et al. 1991, Chico et al. 1997, this report; R. robustus: Espinoza 1955, Amunárriz 1991, Amunárriz et al. 1991, Chico et al. 1997, this report; $b$ : Napo and Orellana were separated into two provinces in 1998. 
cated in Andean life zones over 2,200 m; data available indicate that the species has only been found there in human environments, but this does not preclude its presence in wild habitats as well. Control of this species should contemplate the possibility of re-infestations from wild populations; treating of infested homes and a strong surveillance component must therefore be recommended.

$R$. pictipes and $R$. robustus are recorded from the Ecuadorian Amazon - where seropositivity ranges from $0.8 \%$ to $6 \%$ (cf. Aguilar et al. 1999). We recently studied their presence in palm trees in the Ecuadorian Amazon region. Forty-six percent out of 56 palms surveyed were positive, including five genera (Attalea, Astrocaryum, Oenocarpus, Phytelephas, and Elaeis) (Palomeque et al. 2000). Several specimens labelled as $R$. robustus collected in western Ecuador (Loja and Los Ríos), are deposited at the H. Lent Collection (Instituto Oswaldo Cruz). This finding is most likely related to erroneous capture sites indicated on labels. Our investigations confirm that $R$. stali, a synanthropic species close to $R$. pictipes (Lent et al. 1993), is not known in the Ecuadorian Amazon.

P. rufotuberculatus is truly domestic in some areas of southern Ecuador, where breeding colonies have been found inside dwellings (Avilés et al. 1995b, Abad-Franch 2000). Similar behaviour has also been reported from Bolivia (Noireau et al. 1995, Dujardin et al. 1998) and Peru (Lizaraso 1955, Calderón et al. 1985). Adult insects may also invade houses attracted to electric light (Lent \& Wygodzinsky 1979, Salomón et al. 1999). The

\section{TABLE III}

Distribution and epidemiological significance of the Panstrongylus Berg species in Ecuador

\begin{tabular}{|c|c|c|c|}
\hline Species & $\begin{array}{l}\text { Distribution } \\
\text { (provinces) }^{a}\end{array}$ & $\begin{array}{l}\text { Epidemiological } \\
\text { significance }\end{array}$ & Observations \\
\hline $\begin{array}{l}\text { Panstrongylus } \\
\text { geniculatus } \\
\text { (Latreille) }\end{array}$ & $\begin{array}{l}\text { Imbabura, Manabí, } \\
\text { Pichincha, Esmeraldas, } \\
\text { Sucumbíos, } \\
\text { Napo/Orellana }^{b}\end{array}$ & $\begin{array}{l}\text { Possibly involved in the } \\
\text { transmission of Trypanosoma } \\
\text { cruzi in some areas; adults } \\
\text { flying into houses; reports } \\
\text { of a trend towards } \\
\text { domiciliation in Brazil }\end{array}$ & $\begin{array}{l}\text { Broad distribution (from Argentina to } \\
\text { Mexico); it can be found on both } \\
\text { slopes of the Andes (slight but } \\
\text { noticeable chromatic differences } \\
\text { recorded between both populations) }\end{array}$ \\
\hline $\begin{array}{l}\text { Panstrongylus } \\
\text { rufotuberculatus } \\
\text { (Champion) }\end{array}$ & $\begin{array}{l}\text { Imbabura, Pichincha, } \\
\text { Manabí, Loja, El Oro, } \\
\text { Los Ríos, Guayas }\end{array}$ & $\begin{array}{l}\text { Locally important in areas of } \\
\text { the south, where it is truly } \\
\text { domestic }\end{array}$ & $\begin{array}{l}\text { Western slope of the Andes in } \\
\text { Ecuador, but broad distribution in the } \\
\text { Americas (from Argentina to Mexico) }\end{array}$ \\
\hline $\begin{array}{l}\text { Panstrongylus } \\
\text { howardi } \\
\text { (Neiva) }\end{array}$ & Manabí & $\begin{array}{l}\text { Unclear; adults found within } \\
\text { human dwellings }\end{array}$ & $\begin{array}{l}\text { Endemic species apparently restricted } \\
\text { to a small geographical area; biology, } \\
\text { sylvatic habitats and hosts unknown }\end{array}$ \\
\hline $\begin{array}{l}\text { Panstrongylus } \\
\text { chinai } \\
\text { (del Ponte) }\end{array}$ & Loja, El Oro & $\begin{array}{l}\text { Unclear; reports on domestic } \\
\text { colonies }\end{array}$ & Mainly sylvatic; southwestern region \\
\hline $\begin{array}{l}\text { Panstrongylus } \\
\text { herreri } \\
\text { Wygodzinsky }\end{array}$ & Napo/Orellana ${ }^{b}$ & $\begin{array}{l}\text { Sylvatic; one female captured } \\
\text { inside a house; domestic in } \\
\text { northern Peru, where it is the } \\
\text { main vector of Chagas disease }\end{array}$ & $\begin{array}{l}\text { Two records by our group in the } \\
\text { Amazon basin; its presence in Ecuador } \\
\text { could explain the record of } P \text {. lignarius } \\
\text { from Azuay (see text and below) }\end{array}$ \\
\hline $\begin{array}{l}\text { Panstrongylus } \\
\text { lignarius } \\
\text { (Walker) }\end{array}$ & Sucumbíos & $\begin{array}{l}\text { Sylvatic; recorded only from } \\
\text { rainforests, with the exception } \\
\text { of Cuenca (Azuay) in Ecuador } \\
\text { (thus probably erroneous) }\end{array}$ & $\begin{array}{l}\text { Only two records (western slope of } \\
\text { Andes); its relation with } P \text {. herreri } \\
\text { needs further investigation (a sylvatic } \\
\text { specimen with mixed characters was } \\
\text { collected in northern Ecuador } \\
\text { Amazon); the record of the species in } \\
\text { Azuay is probably due to } \\
\text { misidentification or a labelling error }\end{array}$ \\
\hline
\end{tabular}

a: reports on distribution: P. geniculatus: Espinoza 1955, Rodríguez 1959, Defranc 1982, Amunárriz 1991, Amunárriz et al. 1991, Chico et al. 1997, this report; P. rufotubercutalus: Lazo 1985, Defranc 1982, Reyes 1992, this report; $P$. howardi: Defranc 1982, Lent \& Wygodzinsky 1979, this report; P. chinai: Defranc 1982, Lent \& Wygodzinsky 1979, Reyes 1992; P. herreri: Lent \& Wygodzinsky 1979, Aguilar et al. 1999, this report; P. lignarius: Rodríguez 1961, Defranc 1987, Lent \& Wygodzinsky 1979, this report; $b$ : Napo and Orellana were separated into two provinces in 1998 . 
epidemiological significance of this species deserves further research in southern Ecuador. The possibility that this species colonises houses after domiciliated species are eliminated by control interventions has to be taken into account by control managers. The species occurs mainly in low, dry areas, but may also be found in zones of very humid premontane forest in northern Ecuador, where it is sylvatic but has been captured in houses when flying attracted to light.

TABLE IV

Main biogeographical traits of Ecuadorian Triatominae

\begin{tabular}{|c|c|c|c|c|}
\hline Life zones & Temperature $\left({ }^{\circ} \mathrm{C}\right)$ & Altitude (m) & Annual rains (mm) & Species $^{a}$ \\
\hline Tropical desert & 24 & $0-300$ & $62.5-125$ & $\begin{array}{l}\text { Triatoma dimidiata } \\
\text { Rhodnius ecuadoriensis }\end{array}$ \\
\hline Thick tropical bush & $24-26$ & $0-300$ & $250-500$ & $\begin{array}{l}\text { T. dimidiata } \\
\text { Panstrongylus geniculatus } \\
P . \text { howardi }\end{array}$ \\
\hline Very dry tropical forest & $24-26$ & $0-300$ & $500-1,000$ & $\begin{array}{l}\text { T. dimidiata } \\
R . \text { ecuadoriensis } \\
P . \text { rufotuberculatus } \\
P \text {. chinai } \\
P . \text { howardi }\end{array}$ \\
\hline Dry premontane forest & $18-24$ & 300 & $500-1,000$ & $\begin{array}{l}\text { T. dimidiata } \\
T . \text { carrioni } \\
\text { R. ecuadoriensis } \\
P . \text { rufotuberculatus } \\
P . \text { chinai } \\
\text { Eratyrus cuspidatus }\end{array}$ \\
\hline Dry low montane forest & $12-18$ & $2,000-2,900$ & $500-1,000$ & $\begin{array}{l}\text { T. } \text { carrioni } \\
\text { T. dimidiata } \\
\text { P. chinai }\end{array}$ \\
\hline Dry tropical forest & $24-25$ & $0-300$ & $1,000-2,000$ & $\begin{array}{l}\text { T. dimidiata } \\
P . \text { geniculatus } \\
\text { P. rufotuberculatus }\end{array}$ \\
\hline Humid premontane forest & $18-24$ & $300-1800$ & $1,000-2,000$ & $\begin{array}{l}\text { T. carrioni } \\
\text { T. venosa } \\
R . \text { ecuadoriensis } \\
P . \text { chinai }\end{array}$ \\
\hline Humid low montane forest & $12-18$ & $2,000-2,900$ & $1,000-2,000$ & T. carrioni \\
\hline Moist tropical forest ${ }^{c}$ & $24-25$ & $\begin{array}{c}0-300 \mathrm{~W} \\
\text { up to } 600 \mathrm{E}\end{array}$ & $2,000-4,000$ & $\begin{array}{l}\text { T. dispar } \\
R . \text { pictipes } \\
R . \text { robustus } \\
P . \text { geniculatus } \\
P . \text { herreri/lignarius } \\
\text { E. cuspidatus }(\mathrm{W}) \\
\text { E. mucronatus }(\mathrm{E}) \\
\text { Cavernicola pilosa }\end{array}$ \\
\hline Wet premontane forest & $18-24$ & $\begin{array}{l}300-1,800 \mathrm{~W} \\
600-1,800 \mathrm{E}\end{array}$ & $2,000-4,000$ & $\begin{array}{l}\text { T. carrioni } \\
\text { T. dispar } \\
\text { T. venosa } \\
\text { R. ecuadoriensis } \\
\text { P. geniculatus } \\
\text { P. rufotuberculatus }\end{array}$ \\
\hline Wet low montane forest & $18-24$ & $1,000-1,800$ & $2,000-4,000$ & R. robustus \\
\hline
\end{tabular}

W: western slope of the Andes (Pacific side); E: eastern slope of the Andes (Amazon side), $a$ : dubious records excluded; $b$ : this record corresponds to one specimen labelled as collected in the city of Loja, and has to be regarded with caution as no further nor previous reports have been made; $c$ : see footnote in Results. 
$P$. geniculatus is broadly distributed throughout the continent, and occurs on both slopes of the Andes. Specimens from the Ecuadorian Amazon and coastal regions display conspicuous, apparently constant chromatic differences. The species has been involved in disease transmission in the Ecuadorian Amazon foci (cf. Aguilar et al. 1999). It seems to be readily attracted to electric light (Lent $\&$ Wygodzinsky 1979), and will also approach oil candles in the Ecuadorian Amazon (FS Palomeque, pers. commun.). Peridomestic colonies have been reported from the Brazilian Amazon (Valente et al. 1998, Valente 1999), but reports of domiciliation in Ecuador (Amunárriz 1991, Chico et al. 1997) need confirmation. The species is to be considered as a potential secondary vector in its distribution areas.

P. howardi, a little known species endemic to a dry area of Manabí, is quite commonly found entering human dwellings - as adult specimens, except for one report of a breeding colony in a peridomicile (Defranc 1982). Its sylvatic habitats and hosts remain unknown. The possibility that $P$. howardi transmits $T$. cruzi to people by colonising or invading human-related structures points to the necessity for entomological studies of this species.

$P$. chinai probably also plays a role in the wild cycle of $T$. cruzi transmission in some areas of southern Ecuador and northern Peru, but only few data are available. It has been found to breed in chicken coops and, occasionally, in human dwellings. Adults may be attracted to artificial light (Lent \& Wygodzinsky 1979). The species may also behave as a secondary vector, thus entomological surveillance is a key for the success of control activities.

$P$. herreri has only been reported once from Ecuador (Aguilar et al. 1999). It is domestic in northern Peru, where it is the main vector of Chagas disease (Herrer 1956, 1977, Lent \& Wygodzinsky 1979, Calderón et al. 1985). We recently identified a female $P$. herreri captured in a dwelling of an indigenous village in the province of Napo, confirming our previous record. We also examined a $P$. lignarius female (captured in primary rainforest) which has some mixed characters of $P$. lignarius and herreri. These closely related species showed reproductive compatibility under laboratory conditions (Barrett 1988), but no hybrids have been reported from nature (Lent \& Wygodzinsky 1979). Their taxonomic status needs to be clarified as it has epidemiological implications. The only previous record of P. lignarius in Ecuador (in the Andean highlands city of Cuenca, province of Azuay) (Rodríguez 1959) may be due to misidentification with $P$. herreri, or to an erroneous capture site indicated on the label.
Other Triatominae species (T. dispar, T. venosa, Eratyrus mucronatus, E. cuspidatus and Cavernicola pilosa) seem to have little or no epidemiological significance in Ecuador; Figure and Table I show the main trends. Three of them ( $T$. venosa, E. cuspidatus, and E. mucronatus) have however been reported to show some degree of synanthropism in different countries (Lent \& Wygodzinsky 1979, D’Alessandro \& Barreto 1985, Noireau et al. 1994), but seem to be mainly sylvatic in Ecuador.

The Ministry of Public Health is currently developing the strategy for the control of vector-borne Chagas disease in Ecuador. It will be based on updated information about the distribution and synanthropic behaviour of different triatomine species. The presence of a wide variety of them $(\sim 12 \%$ of all recognised species, and $\sim 18 \%$ of South American species), in their majority present in wild environments, will be one of the main difficulties. Only one of these species, T. dimidiata, may be suspected of having been artificially introduced and therefore susceptible to eradication. The possibility that some southern domestic populations of $R$. ecuadoriensis are isolated from wild foci must be ascertained; if so, local elimination might also be attainable. Autochthonous species may behave as secondary vectors, occupying empty niches when domestic triatomines are eliminated by insecticide spraying. Various species are in their way to true domestication, while others show ability to invade houses without establishing breeding colonies there. A strong component of longitudinal vigilance with community involvement is recommended in such situations, complementing the use of residual pyrethroids (Dias 1991, Dias \& Schofield 1999, Acevedo et al. 2000, Schofield 2000). This work aims to be a contribution to the development of the technical basis for the National Control Programme currently in preparation (including definition of risk areas, sero-entomological surveys, spraying interventions, and the establishment of longitudinal surveillance systems), and to provide researchers and public health authorities with baseline knowledge indispensable for the design of adequate strategies.

\section{ACKNOWLEDGEMENTS}

To CJ Schofield and J Jurberg for their help during the preparation of this work. To AG Guevara (Vozandes Hospital, Quito) and J Racines V (National Institute of Hygiene, Quito) for providing us with entomological records from their fieldwork, and to $\mathrm{G}$ Onore and $\mathrm{M}$ Webb for permitting us to review the material deposited at the Invertebrate Museum of the Catholic University of Quito and the Natural History Museum (London), respectively. 


\section{REFERENCES}

Abad-Franch F 2000. Ecology and Genetics of Chagas Disease Vectors in Ecuador. Implications for the Design of Control Strategies, MPhil to PhD Upgrading Report, London School of Hygiene and Tropical Medicine, University of London, UK, $150 \mathrm{pp}$.

Abad-Franch F, Noireau F, Paucar CA, Aguilar VHM, Carpio CC, Racines VJ 2000. The use of live bait traps for the study of sylvatic Rhodnius populations (Hemiptera: Reduviidae) in palm trees. Trans $R$ Soc Trop Med Hyg 94: 629-630.

Acevedo F, Godoy E, Schofield CJ 2000. Comparison of intervention strategies for control of Triatoma dimidiata in Nicaragua. Mem Inst Oswaldo Cruz 95: 867-871.

Aguilar VHM, Abad-Franch F, Paucar CA, Racines VJ 1999. Epidemiology of Chagas disease in Ecuador. A brief review. Mem Inst Oswaldo Cruz 94 (Suppl. I): 387-393.

Amunárriz MU 1991. Enfermedad de Chagas. Primer foco amazónico. In MU Amunárriz, Estudios sobre Patologías Tropicales en la Amazonía Ecuatoriana, Ed. CICAME, Pompeya, Napo, Ecuador, p. 27-37.

Amunárriz MU, Chico ME, Guderian RH 1991. Chagas disease in Ecuador: a sylvatic focus in the Amazon region. J Trop Med Hyg 94: 145-149.

Avilés H, Cevallos P, Champaloux B, Goujon C, Lema F, Pajony R, Pays JF, Racines VJ, Romaña CA 1995a. Rhodnius ecuadoriensis en áreas endémicas de tripanosomiasis americana en Ecuador. Parasitol al Día 19 (No. extraordinario): 231.

Avilés H, Cevallos P, Champaloux B, Goujon C, Lema F, Pajony R, Pays JF, Racines VJ, Romaña CA 1995b. Panstrongylus rufotuberculatus y características de la vivienda en la provincia de El Oro, Ecuador. Parasitol al Día 19 (No. extraordinario): 230.

Bargues MD, Marcilla A, Ramsey JM, Dujardin JP, Schofield CJ, Mas-Coma S 2000. Nuclear rDNAbased molecular clock of the evolution of Triatominae (Hemiptera: Reduviidae), vectors of Chagas disease. Mem Inst Oswaldo Cruz 95: 567573.

Barrett TV 1988. Current research on Amazonian Triatominae. Mem Inst Oswaldo Cruz 83 (Suppl I): 441-447.

Calderón FGE, Figueroa K, Náquira F, Carcavallo RU, Canale DM 1985. Perú. In RU Carcavallo, JE Rabinovich, RJ Tonn (eds), Factores Biológicos y Ecológicos de la Enfermedad de Chagas, vol. II, CPEHS OPS/OMS, SNCh, Ministerio de Salud y Acción Social, República Argentina, p. 449-456.

Cañadas L 1983. Mapa Bioclimático y Ecológico del Ecuador, MAG-PRONAREG, Quito, Ecuador.

Cañadas L, Estrada W 1978. Ecuador Mapa Ecológico, MAG-PRONAREG, Quito, Ecuador.

Carcavallo RU, Martínez A 1985. Biología, ecología y distribución geográfica de los triatominos americanos. In RU Carcavallo, JE Rabinovich, RJ Tonn (eds), Factores Biológicos y Ecológicos en la Enfermedad de Chagas, Vol. I. CPEHS OPS/OMS, SNCh, Ministerio de Salud y Acción Social,
República Argentina.

Carcavallo RU, Curto de Casas SI, Sherlock IA, Galíndez Girón I, Jurberg J, Galvão C, Mena Segura CA, Noireau F 1999 Geographical distribution and altilatitudinal dispersion. In RU Carcavallo, I Galíndez Girón, J Jurberg, H Lent (eds), Atlas of Chagas Disease Vectors in the Americas, vol. III, Editora Fiocruz, Rio de Janeiro, p. 747-792.

Chico HM, Sandoval C, Guevara EA, Calvopiña HM, Cooper PJ, Reed SG, Guderian RH 1997. Chagas disease in Ecuador: evidence for disease transmission in an indigenous population in the Amazon region. Mem Inst Oswaldo Cruz 92: 317-320.

D’Alessandro A, Barreto P 1985. Colombia. In RU Carcavallo, JE Rabinovich, RJ Tonn (eds), Factores Biológicos y Ecológicos de la Enfermedad de Chagas, vol. II, CPEHS OPS/OMS, SNCh, Ministerio de Salud y Acción Social, República Argentina, p. 377-399.

Defranc MI 1982. Enfermedad de Chagas, Ed. Casa de la Cultura Ecuatoriana, Núcleo del Guayas, Guayaquil.

Defranc MI 1987. Prevalencia de la enfermedad de Chagas en el Ecuador. Informe 1983-1986. Rev Ecuat Hig Med Trop 37: 13-47.

Dias JCP 1991. Chagas disease control in Brazil: which strategy after the attack phase? Ann Soc Belge Med Trop 71 (Suppl. I): 75-86.

Dias JCP, Schofield CJ 1999. The evolution of Chagas disease (American Trypanosomiasis) control after 90 years since Carlos Chagas discovery. Mem Inst Oswaldo Cruz 94 (Suppl. 1): 103-121.

Dodson CH, Gentry AH 1991. Biological extinction in western Ecuador. Ann Missouri Botanical Garden 78: 273-295.

Dujardin JP, Forgues G, Torrez M, Martínez E, Córdoba C, Gianella A 1998. Morphometrics of domestic Panstrongylus rufotuberculatus in Bolivia. Ann Trop Med Parasitol 92: 219-228.

Espinoza LA 1955. Epidemiología de la enfermedad de Chagas en la República del Ecuador. Rev Ecuat Hig Med Trop 12: 25-105.

Herrer A 1956. Observaciones sobre la enfermedad de Chagas en la Provincia de Moyobamba (Depto. de San Martín). Rev Medicina Experimental Lima 10: 59-74.

Herrer A 1977. Reseña de la Entomología Médica en el Perú. I. Principales aspectos entomológicos en la bartonellosis, la trypanosomiasis y la leishmaniasis. Rev Per Entomol 20: 19-24.

Holdridge LR 1967. Life Zone Ecology, Tropical Science Center, San José, Costa Rica.

IGM-Instituto Geográfico Militar 1978-82. Índice Toponímico de la República del Ecuador, Publicación del Instituto Geográfico Militar (A-Q), Quito, Ecuador.

IGM-Instituto Geográfico Militar 1982-96. Índice Toponímico de la República del Ecuador, Publicación del Instituto Geográfico Militar (Q-Z), Quito, Ecuador.

Lazo R 1985. Ecuador. In RU Carcavallo, JE Rabinovich, RJ Tonn (eds), Factores Biológicos y Ecológicos de 
la Enfermedad de Chagas, vol. II, CPEHS OPS/ OMS, SNCh, Ministerio de Salud y Acción Social, República Argentina, p. 413-427.

Lent H, Wygodzinsky P 1979. Revision of the Triatominae (Hemiptera, Reduviidae), and their significance as vectors of Chagas disease. Bull Am Mus Nat History 163: 123-520.

Lent H, Jurberg J, Galvão C 1993. Rhodnius stali n. sp., afim de Rhodnius pictipes Stal, 1872 (Hemiptera: Reduviidae: Triatominae). Mem Inst Oswaldo Cruz 88: 605-614.

León LA 1949. Información sobre el problema de la enfermedad de Chagas en el Ecuador. Bol Ofic Sanit Panam 28: 569-585.

Lizaraso Y 1955. Nota sobre el hallazgo de Triatoma dimidiata y Panstrongylus rufotuberculatus en el Perú. Rev Med Experimental Lima 9: 119-121.

Marcilla JA, Bargues MD, Ramsey JM, MagallónGastélum E, Salazar-Schettino PM, Abad-Franch F, Dujardin JP, Schofield CJ, Mas-Coma S 2001. The ITS-2 of the nuclear rDNA as a molecular marker for populations, species, and phylogenetic relationships in Triatominae (Hemiptera: Reduviidae), vectors of Chagas disease. Mol Phylogenet Evol 18: 136-142.

Meggers BJ, Evans C 1963. Aboriginal Cultural Development in Latin America: an Interpretative Review, Smithsonian Miscellaneous Collections, vol. 146, no.1, The Smithsonian Institution, Washington DC, USA.

Miranda J 1995. Elementos de Cartografía Básica, Colección de Documentos Didácticos no.1, Centro Panamericano de Estudios e Investigaciones Geográficas, Quito, Ecuador.

Noireau F, Bosseno MF, Carrasco R, Tellería J, Vargas F, Camacho C, Yaksic N, Brenière SF 1995. Sylvatic triatomines (Hemiptera: Reduviidae) in Bolivia: trends towards domesticity and possible infection with Trypanosoma cruzi (Kinetoplastida: Trypanosomatidae). J Med Entomol 32: 594-598.

Palomeque FS, Abad-Franch F, Suárez K, Aguilar VHM 2000. Uso de trampas de cebo vivo para el estudio de poblaciones silvestres de Rhodnius (Reduviidae: Triatominae) en palmeras de la Amazonia Ecuatoriana. Memorias, XIV Jornadas Equatorianas de Biología, p. 108.

Romaña C, Racines VJ, Avilés H, Lema F 1994.
Observaciones de domiciliación de Rhodnius ecuadoriensis en focos endémicos de la enfermedad de Chagas en el Ecuador. Microbiología 1: 59.

Reyes LV 1992. Enfermedad de Chagas. In R Sempértegui, P Naranjo, M Padilla (eds), Panorama Epidemiológico del Ecuador, Ministerio de Salud Pública, UNICEF, Quito, Ecuador, p. 134-137.

Rodríguez JD 1959. Epidemiología de la enfermedad de Chagas en la República del Ecuador. Rev Goiana Med 5: 411-438.

Rodríguez JD 1961. Nuevos datos sobre la enfermedad de Chagas en Guayaquil. Rev Ecuat Hig Med Trop 18: 48-52.

Salomón OD, Ripoll CM, Rivetti E, Carcavallo RU 1999. Presence of Panstrongylus rufotuberculatus (Champion, 1899) (Hemiptera: Reduviidae: Triatominae) in Argentina. Mem Inst Oswaldo Cruz 94: 285-288.

Schofield CJ 2000. Challenges of Chagas disease vector control in Central America. Position paper WHO/ CDS/WHOPES/GCDPPH/2000.1. WHO, Communicable Diseases Control, Prevention and Eradication, WHO Pesticide Evaluation Scheme (WHOPES), Geneva, Switzerland.

Schofield CJ, Diotaiuti L, Dujardin JP 1999. The process of domestication in Triatominae. Mem Inst Oswaldo Cruz 94 (Suppl. I): 375-378

Solís-Mena S, Patterson JS, Abad-Franch F 2000. Studying the origin of Ecuadorian Triatoma dimidiata populations (Hemiptera: Reduviidae: Triatominae). Poster, The Trypanosome Evolution Workshop, University of Exeter/London School of Hygiene and Tropical Medicine, London, UK.

Valente VC 1999. Potential for domestication of Panstrongylus geniculatus (Latreille, 1811) (Liemiptera, Reduviidae, Triatominae) in the municipality of Muará, Marajó Island, State of Pará, Brazil. Mem Inst Oswaldo Cruz 94 (Suppl. I): 399-400.

Valente VC, Valente SAS, Noireau F, Carrasco HJ, Miles MA 1998. Chagas disease in the Amazon basin: association of Panstrongylus geniculatus (Hemiptera: Reduviidae) with peridomestic pigs. J Med Entomol 35: 99-103.

WHO-World Health Organization 1991. Control of Chagas disease. WHO Technical Report Series 811.

Zeledón R 1981. El Triatoma dimidiata y su Relación con la Enfermedad de Chagas, Ed. Universidad Estatal a Distancia, San José, Costa Rica, 146 pp. 